\title{
ANALISIS TINGKAT PENCEMARAN MUARA SUNGAI KURAU KABUPATEN BANGKA TENGAH DITINJAU DARI INDEKS SAPROBITAS PLANKTON
}

\author{
Indah Puspita Sari ${ }^{1}$, Eva Utami S.Si., M.Si ${ }^{2}$, Umroh S.T., M.Si ${ }^{3}$ \\ ${ }^{1}$ Mahasiswa Jurusan Manajemen Sumberdaya Perairan, FPPB Universitas Bangka Belitung \\ Email : indahpuspita895@gmail.com \\ ${ }^{2}$ Staf Pengajar Jurusan Manajemen Sumberdaya Perairan, FPPB Universitas Bangka Belitung \\ ${ }^{3}$ Staf Pengajar Jurusan Ilmu Kelautan, FPPB Universitas Bangka Belitung
}

\begin{abstract}
ABSTRAK
Muara sungai merupakan ekosistem yang produktif karena adanya penambahan bahan organik dan anorganik yang berasal dari air sungai dan air laut. Muara Sungai Kurau diduga telah mengalami pencemaran akibat aktivitas domestik yang terjadi di daerah tersebut. Penelitian ini bertujuan untuk menganalisis tingkat pencemaran Muara Sungai Kurau berdasarkan parameter biologi (plankton) dengan indeks saprobitas plankton serta menganalisis pengaruh parameter lingkungan terhadap kelimpahan organisme plankton. Pengamatan dilakukan berdasarkan analisis SI (Saprobik Indeks) dan TSI (Tropik Saprobik Indeks) dari sampel air yang di ambil di Muara Sungai Kurau bulan Januari-Februari 2017. Hasil penelitian menunjukkan nilai SI dan TSI Stasiun I dan II berkisar pada 1,24 s/d 1,37 dan 1,49 s/d 1,5 yang termasuk $\beta$ - Mesosaprobik atau tercemar ringan hingga sedang, sedangkan nilai SI dan TSI stasiun III yakni 1,56 dan 2,52 termasuk oligosaprobik atau tercemar ringan/belum tercemar. Berdasarkan kriteria, maka kualitas biologis perairan Muara Sungai Kurau termasuk tercemar ringan hingga sedang. Berdasarkan analisis koefisien korelasi, parameter salinitas, kecepatan arus, COD dan nitrat memiliki korelasi yang sangat kuat $(0,80-1,00)$, parameter BOD memiliki korelasi yang cukup $(0,40-0,599)$, parameter kedalaman memiliki korelasi kuat $(0,60-0,799)$, sedangkan parameter TSS, DO, suhu, $\mathrm{pH}$ dan phosfat memiliki korelasi sangat lemah $(0,00-0,199)$.
\end{abstract}

Kata kunci: Muara Sungai Kurau, Saprobik Indeks, Tropik Saprobik Indeks, Plankton

\section{PENDAHULUAN}

Desa Kurau berdasarkan letak geografisnya berada pada titik koordinat $2^{\circ} 19^{\prime} 52.64$ " LU dan $106^{\circ} 14^{\prime} 00.17^{\prime \prime}$ BT terletak di Kecamatan Koba Kabupaten Bangka Tengah Provinsi Kepulauan Bangka Belitung. Desa Kurau merupakan salah satu desa yang pemukiman warganya tepat berada di Daerah Aliran Sungai (DAS) Kurau yakni di bagian Muara Sungai Kurau yang langsung berhadapan dengan perairan laut. Daerah Aliran Sungai (DAS) Kurau memiliki panjang sekitar 60,16 km dengan luas sungai $657,69 \mathrm{~km}^{2}$. Bagian hulu Sungai Kurau berada di Sungai Paku Kecamatan Payung Kabupaten Bangka Selatan dan hilirnya berada di Desa Kurau Kabupaten Bangka Tengah (BLHD Provinsi Bangka Belitung. 2015)

Muara Daerah Aliran Sungai (DAS) Kurau oleh warga dimanfaatkan untuk kegiatan domestik seperti tempat pelelangan ikan, tempat bersandarnya kapalkapal nelayan, alur keluar masuknya kapal-kapal nelayan serta pemukiman penduduk. Kegiatan domestik yang berada disepanjang aliran muara sungai ini tentu saja menghasilkan limbah berupa limbah organik dan anorganik seperti limbah dari kegiatan rumah tangga (hasil mencuci piring, mandi, buang air besar, buang air kecil dan mencuci pakaian). Limbah dari kegiatan rumah tangga ini dialirkan dan di buang ke perairan melalui saluran (bandar/got) yang bagian ujungnya mengarah langsung ke muara sungai.

Aktivitas manusia yang terjadi di sekitar muara sungai akan memberikan dampak pencemaran perairan. Menurut Suryanto et al. (2014) limbah yang dihasilkan dari kegiatan manusia yaitu pembuangan sampah secara sembarangan dapat menimbulkan bau tidak sedap dan mengganggu kesehatan manusia. Dampak lainnya yang ditimbulkan bagi perairan yakni terjadinya gangguan serta perubahan fisik, kimia dan biologi pada perairan sungai tersebut dan akhirnya menyebabkan pencemaran.

Berdasarkan PP No. 82/2001 tentang Pengelolaan Kualitas Air dan Pengendalian Pencemaran Air, mendefinisikan pencemaran air adalah masuknya atau dimasukanya makhluk hidup, zat, energi dan atau komponen lain ke dalam air oleh kegiatan manusia, sehingga kualitas air turun sampai ke tingkat tertentu yang menyebabkan air tidak dapat berfungsi sesuai dengan peruntukanya. Sedangkan, menurut Salmin (2005) pencemaran air merupakan kondisi dimana adanya penambahan unsur atau organisme ke dalam air, sehingga pemanfaatannya dapat terganggu.

Pencemaran perairan diindikasikan dengan berubahnya kualitas perairan. Perubahan pada kualitas perairan terutama perairan muara sungai yang banyak dipengaruhi oleh aktivitas manusia perlu dilakukan pemantauan dan pegelolaan. Metode yang digunakan untuk menentukan kualitas perairan pada sungai harus dengan metode yang tepat dan teliti, sehingga dapat dilakukaan tindakan pencegahan terhadap penyebaran bahan polutan serta dapat menyelamatkan kehidupan biota di perairan. Metode yang dapat digunakan untuk menganalisis tingkat pencemaran di perairan salah satunya dengan indeks saprobitas plankton (Basmi. 2000) 
Saprobitas menurut Basmi (2000) adalah keadaan dimana adanya penambahan bahan organik ke dalam perairan yang biasanya indikatornya adalah jumlah dan susunan spesies dari organisme yang ada di dalam perairan tersebut. Organisme yang dapat dijadikan sebagai indikator penentu kualitas perairan dengan saprobitas salah satunya adalah fitoplankton.

\section{Tujuan Penelitian}

1. Menganalisis tingkat pencemaran perairan Muara Sungai Kurau berdasarkan parameter biologi (plankton) dengan indeks saprobitas plankton.

2. Menganalisis pengaruh parameter lingkungan terhadap kelimpahan organisme plankton.

\section{Manfaat Penelitian}

1. Sebagai informasi kepada masyarakat tentang tingkat pencemaran di Muara Sungai Kurau.

2. Sebagai referensi bagi para peneliti yang ingin mempelajari tentang kualitas perairan dengan indeks saprobitas di Muara Sungai Kurau.

\section{METODE PENELITIAN \\ Waktu dan Tempat Penelitian}

Penelitian ini dilaksanakan pada bulan Januari Februari tahun 2017. Lokasi penelitian dilakukan di Muara Sungai Kurau, Kecamatan Koba, Kabupaten Bangka Tengah, Provinsi Kepulauan Bangka Belitung.

Pengukuran sampel kualitas air dilakukan dengan dua cara, yakni secara langsung di lapangan (in situ) dan dilakukan secara tidak langsung (ex situ) di Laboratorium Perikanan, Fakultas Pertanian Perikanan dan Biologi Universitas Bangka Belitung, di Laboratorium Kesehatan Daerah Provinsi Bangka Belitung dan di Laboratorium Lembaga Ilmu (LIPI) Pusat Penelitian Oseanografi Jakarta.

\section{Alat dan Bahan}

Alat yang digunakan dalam penelitian adalah Plankton Net ukuran $25 \mu \mathrm{m}$ untuk menyaring plankton, botol sampel untuk wadah sampel dan GPS untuk menentukan letak posisi georafis. Sedangkan bahan yang digunakan adalah sampel plankton dan sampel air yang di ambil dari tiga stasiun pengambilan sampel di Muara Sungai Kurau.

\section{Prosedur Penelitian \\ Penentuan Lokasi Pengambilan Sampel}

Lokasi pengambilan sampel dilakukan secara purposif untuk mendapatkan sampel yang mewakili lokasi penelitian secara keseluruhan. Dengan demikian lokasi yang dimaksud harus mewakili keadaan sekitar muara sungai di Desa Kurau. Stasiun pengambilan sampel ini dibagi menjadi tiga yang di mulai dari bagian muara yang mengarah ke hulu hingga ke tempat pelelangan ikan, untuk peta lokasi pengambilan sampel dapat dilihat pada Gambar 1.

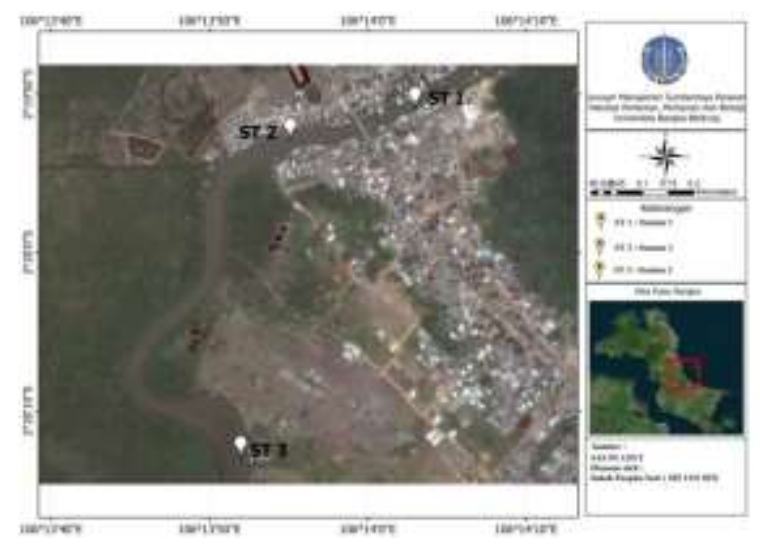

Gambar 1. Peta Lokasi Penelitian

Pengambilan sampel pada tiap stasiun dilakukan ulangan sebanyak 3 (tiga) kali menggunakan ulangan waktu. Berdasarkan penelitian Zahidin (2008), jarak pengambilan sampel 2 (dua) minggu akan memperoleh sampel yang berbeda secara signifikan untuk masingmasing pengambilan sampel. Sampel yang di dapat juga akan lebih mudah di analisa. Pengambilan sampel dilakukan pada pukul 07.00-09.00 WIB, hal ini dikarenakan pada jam tersebut masih terjadinya distribusi vertikal antara fitoplankton dan zooplankton di perairan.

\section{Pengambilan Sampel Plankton}

Pengambilan sampel plankton menggunakan Plankton Net ukuran mata jaring $25 \mu \mathrm{m}$ yang dilakukan secara vertikal dengan kedalaman 2 meter pada masing-masing stasiun. Sampel plankton kemudian di simpan dalam botol sampel yang diawetkan dengan menggunakan lugol 4\% sebanyak 2 -3 tetes (Irawati $e t$ al., 2015). Identifikasi jenis plankton menggunakan alat bantu mikroskop binocular dengan metode sensus/sapuan. Adapun data yang di analisis adalah sebagai berikut :

a. Kelimpahan Plankton

$$
\mathrm{N}=\mathrm{n} \frac{\mathrm{Vr}}{\mathrm{Vo}} \times \frac{1}{\mathrm{Vs}}
$$

Persamaan yang digunakan untuk menghitung kelimpahan plankton adalah persamaan Fachrul (2007) sebagai berikut :

\section{Keterangan :}

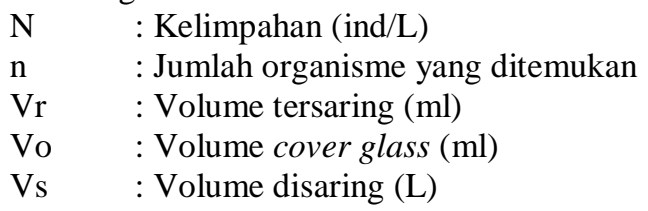

b. Indeks Keanekaragaman Plankton

Indeks keanekaragaman dihitung berdasarkan indeks keanekaragaman Shannon-Wiener (Fachrul. 2007) sebagai berikut : 


$$
\mathrm{H}^{\prime}=\left(\sum \frac{\mathrm{ni}}{\mathrm{N}} \ln \frac{\mathrm{ni}}{\mathrm{N}}\right)
$$

Keterangan :

H' : Indeks Keanekaragaman jenis

$\mathrm{Ni}$ : Jumlah individu masing-masing jenis

$\mathrm{N}$ : Jumlah total individu semua jenis

Dengan kriteria nilai indeks keanekaragaman :

$\mathrm{H}^{\prime}<1$ : Komunitas biota tidak stabil atau kualitas air tercemar berat

$1<\mathrm{H}^{\prime}<3$ : Stabilitas komunitas biota sedang atau kualitas air tercemar sedang

$\mathrm{H}^{\prime}>3$ : Stabilitas komunitas biota dalam kondisi prima (stabil) atau kualitas air bersih

c. Indeks Keseragaman Plankton

Indeks keseragaman (E) dihitung dengan berdasarkan indeks keseragaman Pielou, 1996 (Fachrul. 2007) sebagai berikut :

Keterangan

$$
\mathrm{E}=\frac{\mathrm{H}^{\prime}}{\ln \mathrm{S}}
$$

$\mathrm{E} \quad$ : Indeks keseragaman jenis

$\mathrm{H}^{\prime}$ : Indeks keanekaragaman

$\mathrm{S}$ : Jumlah jenis

Dengan kriteria nilai keseragaman :

$\mathrm{E}=0$ : Keseragaman antara spesies rendah

$\mathrm{E}=1$ : Keseragaman antar spesies relatif seragam

\section{d. Indeks Dominansi}

Untuk mengetahui adanya dominansi jenis tertentu di perairan dapat digunakan indeks dominansi Simpson (Odum, 1997) dengan persamaan sebagai berikut :

$$
\mathrm{D}=\left(\frac{\mathrm{ni}}{\mathrm{N}}\right)^{2}
$$

Keterangan :

D : Indeks dominansi

ni : Jumlah individu tiap spesies

$\mathrm{N}$ : Total individu

e. Saprobik Indeks (SI) dan Tropik Saprobik Indeks (TSI)

Menentukan nilai saprobitas perairan menggunakan analisis Tropik Saprobik yang nilainya ditentukan oleh Saprobik Indeks (SI) dan Tropik Saprobik Indeks (TSI) dengan formulasi Persoone dan De Pauw (Suryanti. 2008) :

$$
S I=\frac{1 C+3 D+1 B-3 A}{1 A+1 B+1 C+1 D}
$$

SI : Saprobik Indeks

A : Jumlah genus/spesies organisme polysaprobik

B :Jumlah genus/spesies organisme $\alpha$ mesosaprobik

C :Jumlah genus/spesies organisme $\quad \beta$ mesosaprobik

D : Jumlah genus/spesies organisme oligsaprobik

$$
\mathrm{TSI}=\frac{1(n \mathrm{C})+3(\mathrm{nD})+1(\mathrm{nB})-3(\mathrm{nA})}{1(\mathrm{nA})+1(\mathrm{nB})+1(\mathrm{nC})+1(\mathrm{nD})} \times \frac{\mathrm{nA}+\mathrm{nB}+\mathrm{nD}+\mathrm{nE}}{\mathrm{nA}+\mathrm{nB}+\mathrm{nC}+\mathrm{nD}}
$$

Keterangan :

$\mathrm{N}$ : Jumlah individu organisme pada setiap kelompok saprobitas

nA : Jumlah individu penyusun kelompok polysaprobik

nB : Jumlah individu penyusun kelompok $\alpha-$ mesosaprobik

nC : Jumlah individu penyusun kelompok $\beta$ mesosaprobik

$\mathrm{nD}$ : Jumlah individu penyusun kelompok oligosaprobik

$\mathrm{nE}$ : Jumlah individu penyusun selain kelompok A, B, C, D

dengan kriteria nilai indeks saprobitas (SI) dan indeks tropik saprobitas (TSI) sebagai berikut :

Tabel 1. Kategori Saprobitas Perairan Berdasarkan Nilai SI dan TSI

\begin{tabular}{lll}
\hline Nilai SI/TSI & Kategori Saprobitas & \multicolumn{1}{c}{ Indikasi } \\
\hline$<-3 \mathrm{~s} / \mathrm{d}-2$ & Polisaprobik & $\begin{array}{l}\text { Pencemaran berat } \\
\text { Pencemaran } \\
\text { sedang sampai } \\
\text { berat }\end{array}$ \\
$0,5 \mathrm{~s} / \mathrm{d} 1,5$ & $\beta-$ Mesosaprobik & $\begin{array}{l}\text { Pencemaran } \\
\text { ringan sampai } \\
\text { sedang } \\
\text { Pencemaran } \\
\text { ringan atau belum } \\
\text { tercemar }\end{array}$ \\
\hline
\end{tabular}

\section{Analisis Data}

1. Analisis Deskriptif

Analisis data tentang indeks saprobitas plankton menggunakan analisis deskriptif, yakni analisis yang digunakan untuk mendapatkan gambaran umum mengenai sebaran data. Analisis deskriptif digunakan untuk dapat menggambarkan situasi dan kondisi pada waktu dan tempat yang terbatas untuk mengetahui situasi dan kondisi lokal suatu lokasi yang dapat dijelaskan pada waktu dan lokasi yang berbeda. Data yang disajikan dalam bentuk tabel dan grafik serta dilakukan interpretasi (Zahidin. 2008)

2. Analisis Korelasi

Keterangan : 


$$
\mathrm{r}=\frac{\mathrm{n}\left(\sum \mathrm{x} \cdot \mathrm{y}\right)-\left(\sum \mathrm{x}\right)\left(\sum \mathrm{y}\right)}{\sqrt{\left\{\mathrm{n}\left(\sum \mathrm{x}^{2}\right)-\left(\sum \mathrm{x}\right)^{2}\right\}\left\{\mathrm{n}\left(\sum \mathrm{y}^{2}\right)-\left(\sum \mathrm{y}\right)^{2}\right\}}}
$$

Analisis korelasi digunakan untuk menegathui parameter fisika kimia perairan yang berkorelasi terhadap nilai kelimpahan plankton. Analisis korelasi menggunakan Korelasi Person yang diperoleh dari persamaan berikut (Siregar. S, 2014) :

Keterangan :

$\mathrm{r} \quad$ : Koefisien Korelasi

$\mathrm{X} \quad$ : Variabel X (nilai kelimpahan)

$\mathrm{Y} \quad$ : Variabel Y (nilai parameter kualitas air)

Menurut (Siregar. S, 2014), untuk memudahkan dalam melakukan iterpretasi mengenai kekuatan hubungan antara dua variabel dibuat kiteria sebagai berikut :

Tabel 2. Kategori Hubungan antara 2 Variabel berdasarkan Koefisien Korelasi

\begin{tabular}{cl}
\hline $\begin{array}{c}\text { Koefisien } \\
\text { korelasi }\end{array}$ & \multicolumn{1}{c}{ Kategori } \\
\hline $0,00-0,199$ & Korelasi sangat lemah \\
$0,20-0,399$ & Korelasi lemah \\
$0,40-0,599$ & Korelasi cukup \\
$0,60-0,799$ & Korelasi kuat \\
$0,80-0,100$ & Korelasi sangat kuat
\end{tabular}

\section{HASIL}

Plankton

Berdasarkan hasil identifikasi jenis plankton yang ditemukan di Muara Sungai Kurau selama bulan Januari - Februari 2017, ditemukan 28 genera yang terdiri dari 6 genera kelompok $\alpha$-mesosaprobik, 4 genera dari kelompok $\beta$-mesosaprobik, 3 genera dari kelompok oligosaprobik dan 15 genera dari kelompok non-saprobik. Hasil identifikasi dan perhitungan kelimpahan individu dapat dilihat pada Tabel 3.

Tabel 3. Nilai Rata-rata Kelimpahan Organisme Plankton pada Masing-masing Stasiun Amatan

\begin{tabular}{|c|c|c|c|c|c|c|}
\hline \multirow{2}{*}{ No. } & \multirow{2}{*}{$\begin{array}{l}\text { Kelompok } \\
\text { Saprobitas }\end{array}$} & \multirow{2}{*}{ Spesies } & \multicolumn{4}{|c|}{ Rata-rata Kelimpahan Individu (Ind/L) } \\
\hline & & & Stasiun 1 & Stasiun 2 & Stasiun 3 & Rata-rata \\
\hline 1 & \multirow{6}{*}{$a$-Mesosaprobik } & Biddulphia sp. & 3.778 & 1370 & 1.859 & 2.336 \\
\hline 2 & & Chaetocerossp. & 9.110 & 10.463 & 4916 & 8.163 \\
\hline 3 & & 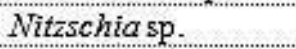 & 1.712 & 587 & 551 & 950 \\
\hline 4 & & Oscillatoriasp. & 123 & 216 & 1.015 & 451 \\
\hline 5 & & Rhizosoleniasp. & 10394 & 7.166 & 5.161 & 7.574 \\
\hline 6 & & Stephanodiscus sp. & 200 & 179 & 277 & 219 \\
\hline 7 & \multirow{4}{*}{$\beta$-Mesosaprobik } & Asterionella sp. & 359 & 188 & 106 & 218 \\
\hline 8 & & Ceratium sp. & 147 & 106 & 49 & 101 \\
\hline 9 & & Melosira & 8 & 0 & 25 & 11 \\
\hline 10 & & Nauplius & 730 & 514 & 367 & 537 \\
\hline 11 & \multirow{3}{*}{ Oligosaprobik } & Skeletonema sp. & 698 & 245 & 428 & 457 \\
\hline 12 & & Synedra & 567 & 78 & 172 & 272 \\
\hline 13 & & Pinnulariasp. & 25 & 0 & 29 & 18 \\
\hline 14 & \multirow{15}{*}{ Non-Saprobik } & Amphorasp. & 131 & 131 & 167 & 143 \\
\hline 15 & & Bacteriastrum sp. & 485 & 1.068 & 1239 & 931 \\
\hline 16 & & Cerataulinasp. & 270 & 432 & 869 & 524 \\
\hline 17 & & Corethronsp & 139 & 351 & 41 & 177 \\
\hline 18 & & Coscinodiscus sp. & 196 & 127 & 65 & 129 \\
\hline 19 & & Ditylum sp. & 579 & 575 & 506 & 553 \\
\hline 20 & & Fragillariasp. & 127 & 171 & 212 & 170 \\
\hline 21 & & Guinardiasp. & 163 & 1.019 & 98 & 427 \\
\hline 22 & & Hemiaulus sp. & 465 & 628 & 391 & 495 \\
\hline 23 & & Lauderiasp. & 322 & 404 & 123 & 283 \\
\hline 24 & & Oncaeasp. & 135 & 347 & 139 & 207 \\
\hline 25 & & Pleurosigmasp. & 302 & 351 & 530 & 394 \\
\hline 26 & & Scenedesmus sp. & 12 & 0 & 4 & 5 \\
\hline 27 & & Thalassionema sp. & 836 & 706 & 530 & 691 \\
\hline 28 & & Thallassionthrix sp. & 1.683 & 697 & 1.879 & 1.420 \\
\hline \multicolumn{3}{|c|}{ Jumlah } & 33.696 & 28.119 & 21.748 & - \\
\hline \multicolumn{3}{|c|}{ Indeks Keanekaragaman $\left(\mathrm{H}^{*}\right)$} & 2,063 & 2,073 & 2,3 & - \\
\hline \multicolumn{3}{|c|}{ Indeks Keseragaman (E) } & 0,287 & 0,3 & 1,007 & - \\
\hline \multicolumn{3}{|c|}{ Indeks Dominansi (C) } & 0,207 & 0,2033 & 0,15 & - \\
\hline
\end{tabular}


Kelimpahan tertinggi pada stasiun 1 dengan kelimpahan plankton sebesar 33.696 ind/1 dan kelimpahan terendah pada stasiun 3 sebesar 21.748 ind/l. Jenis plankton dengan kelimpahan tertinggi yaitu Chaetoceros sp. dengan rata-rata kelimpahan sebesar 8.163 ind/l dan Rhizosolenia sp. dengan rata-rata kelimpahan sebesar 7.574 ind/l. Sementara jenis plankton dengan kelimpahan terendah yaitu Scenedesmus sp. sengan kelimpahan sebesar $5 \mathrm{id} / \mathrm{l}$ dan Melosira.

Nilai rata-rata indeks keanekaragaman, keseragaman dan dominansi pada stasiun I berturutturut yakni 2,063，0,287 dan 0,207. Pada stasiun II berturut-turut yakni 2,073 (H'), 0,3 (E) dan 0,203 (D) serta pada stasiun III berturut-turut yakni 2,3 (H') , 1,007 (E) dan 0,15 (D)

Dari hasil pengamatan, kelimpahan plankton yang paling banyak ditemukan di Perairan Muara Sungai Kurau yakni Chaetoceros sp. dan Rhizosolenia sp. sedangkan jenis plankton yang paling jarang ditemukan yakni Melosira, Pinnularia sp. dan Scenedesmus sp. Untuk lebih jelasnya dapat dilihat pada Gambar 2.

\section{Saprobik Indeks dan Tingkat Saprobik Indeks}

Tingkat pencemaran suatu perairan dapat diketahui dari nilai Saprobik Indeks (SI) dan Tingkat Saprobik Indeks (TSI). Hasil perhitungan nilai SI dan TSI di stasiun III berturut-turut sebesar 1,56 dan 2,52 lebih tinggi dibandingkan dengan stasiun I dan II.

Berdasarkan kriteria tingkat saprobitas perairan, stasiun I dan II termasuk ke dalam kategori $\beta$ Mesosaprobik atau perairan yang tercemar ringan hingga sedang sedangkan stasiun III termasuk ke dalam kategori Oligosaprobik atau perairan yang tercemar ringan. Hasil perhitungan rata-rata nilai SI dan TSI dapat dilihat pada Tabel 4.
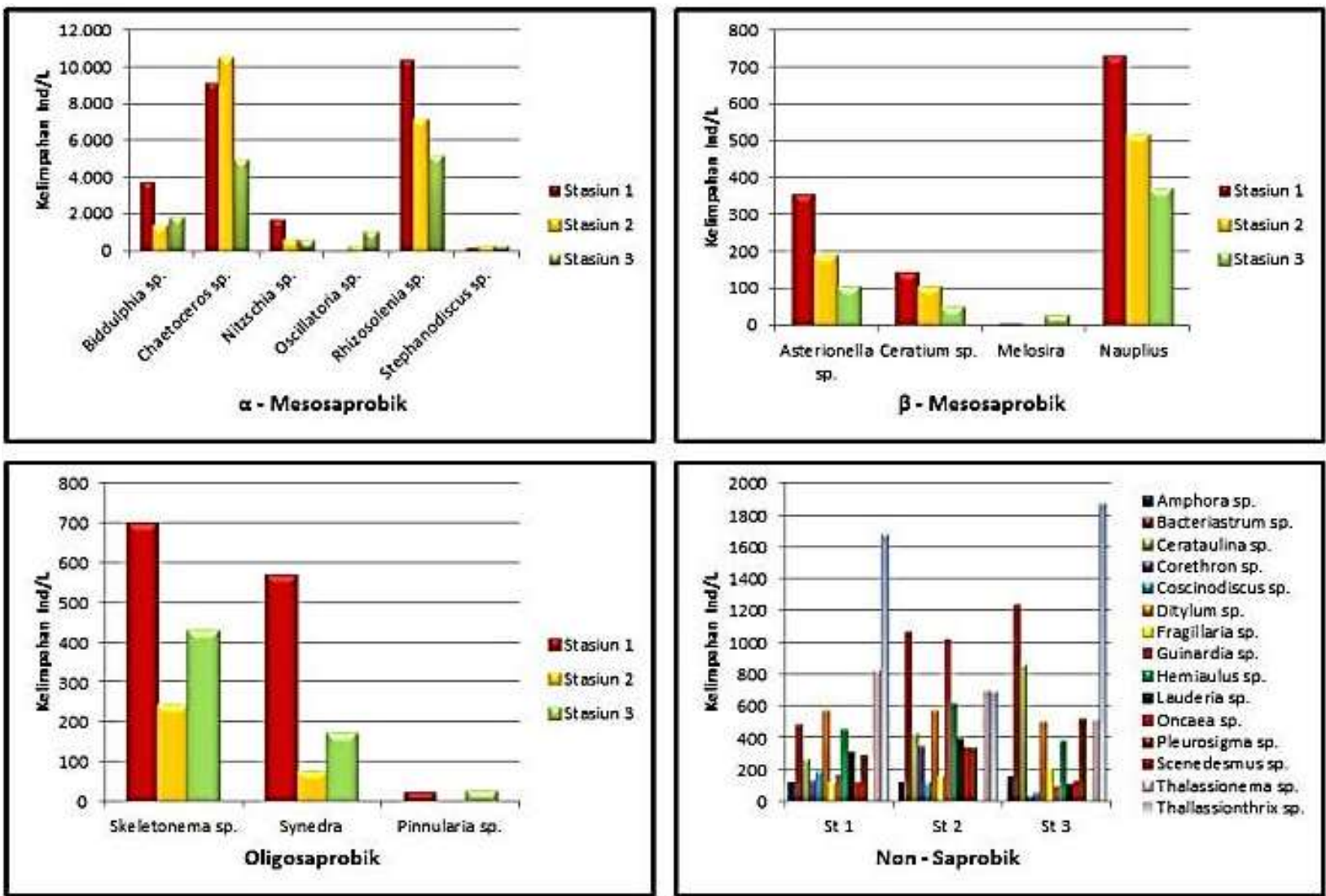

Gambar 2. Grafik kelimpahan plankton kelompok saprobik dan non saprobik pada setiap stasiun di Muara Sungai Kurau

Tabel 4. Hasil Perhitungan Rata-rata Nilai SI dan TSI di Muara Sungai Kurau

\begin{tabular}{|c|c|c|c}
\hline Nilai & Stasiun 1 & Stasiun 2 & Stasiun 3 \\
\hline SI & 1,37 & 1,24 & 1,56 \\
\hline TSI & 1,5 & 1,49 & 2,52 \\
\hline Kategori saprobik & $\beta$-Mesosaprobik & $\beta$-Mesosaprobik & Oligosaprobik \\
\hline
\end{tabular}




\section{Parameter Lingkungan}

Berdasarkan hasil penelitian diketahui bahwa di Perairan Muara Sungai Kurau memiliki rata-rata kedalaman berkisar antara $3-3,8$ meter. Suhu rata-rata perairan selama penelitian yakni $26,7^{\circ} \mathrm{C}$ dengan kadar salinitas berkisar antara 18-18,7 \%o dan $\mathrm{pH}$ sebesar 6 . Parameter lingkungan lain seperti kecepatan arus yang berperan dalam produktivitas primer berkisar antara $0,323-0,363 \mathrm{~m} / \mathrm{s}$, TSS yakni berkisar anatara $133-$ $158 \mathrm{mg} / \mathrm{l}$, kandungan COD berkisar antara $28-38$ $\mathrm{mg} / \mathrm{L}$ serta phosfat dan nitrat berturut-turut berkisar antara $0,0067-0,007 \mathrm{mg} / \mathrm{L}$ dan $0,017-0,025 \mathrm{mg} / \mathrm{l}$ (Tabel 5.).

\section{Pengaruh Parameter Lingkungan terhadap Kelimpahan Plankton}

Hasil pengukuran faktor fisika kimia perairan yang dilakukan pada setiap stasiun amatan yang kemudian dikorelasikan dengan kelimpahan plankton maka diperoleh nilai koefisien korelasi yaitu kelimpahan dengan parameter suhu sebesar 0 , kelimpahan dengan parameter salinitas sebesar 0,846, kelimpahan dengan parameter kecepatan arus sebesar 0,971, kelimpahan dengan parameter $\mathrm{pH}$ sebesar 0 , kelimpahan dengan parameter kedalaman sebesar 0,746 , kelimpahan dengan parameter TSS sebesar 0,148 , kelimpahan dengan parameter DO sebesar 0,038 , kelimpahan dengan parameter BOD sebesar 0,416 , kelimpahan dengan parameter COD sebesar 0,971 , kelimpahan dengan parameter Nitrat sebesar 0,875 , kelimpahan dengan parameter phosfat sebesar 0,028 . Grafik pengaruh parameter lingkungan terhadap kelimpahan plankton dapat dilihat pada Gambar 3.

Tabel 5. Rata-rata Nilai Parameter Lingkungan yang Diperoleh pada Setiap Stasiun Pengamatan di Muara Sungai Kurau

\begin{tabular}{|c|l|c|c|c|c|c|c}
\hline No & \multicolumn{1}{|c|}{ Variabel } & \multicolumn{3}{|c|}{ Stasiun } & $\begin{array}{c}\text { Nilai } \\
\text { Optimum }\end{array}$ & Dasar Pustaka \\
\hline 1 & Suhu Air ( $\left.{ }^{\circ} \mathrm{C}\right)$ & 26,7 & 26,7 & 26,7 & $25^{\circ}-35^{\circ}$ & $\begin{array}{c}\text { Wyrtki (1961) dalam Hartoko } \\
(2013)\end{array}$ \\
\hline 2 & Salinitas (\%o) & 18,7 & 18 & 18 & $5-30$ & Nyabakken (1992) \\
\hline 3 & $\begin{array}{l}\text { Kec. Arus } \\
(\mathrm{m} / \mathrm{s})\end{array}$ & 0,363 & 0,336 & 0,323 & - & - \\
\hline 4 & $\mathrm{pH}$ & 6 & 6 & 6 & $6,5-8,5$ & Effendi (2003) \\
\hline 5 & Kedalaman(m) & 3,6 & 3,8 & 3 & - & - \\
\hline 6 & TSS (mg/) & 155 & 133 & 158 & 50 & $\begin{array}{c}\text { Kriteria Mutu Air Kelas II (PP } \\
\text { no.82/2001) }\end{array}$ \\
\hline 7 & DO (ppm) & 5 & 5,2 & 5 & 4 & $\begin{array}{c}\text { Kriteria Mutu Air Kelas II (PP } \\
\text { no.82/2001) }\end{array}$ \\
\hline 8 & BOD (mgl) & 15,7 & 16,5 & 15,2 & 3 & $\begin{array}{c}\text { Kriteria Mutu Air Kelas II (PP } \\
\text { no.82/2001) }\end{array}$ \\
\hline 9 & COD (mg/) & 28 & 34,8 & 38 & 25 & Permenkes RI no.416/1990 \\
\hline 10 & Nitrat (mg/) & 0,017 & 0,024 & 0,025 & 10 & $\begin{array}{c}\text { Kriteria Mutu Air Kelas II (PP } \\
\text { no.82/2001) }\end{array}$ \\
\hline 11 & Phosfat (mg/) & 0,006 & 0,007 & 0,0067 & 0,2 & $\begin{array}{c}\text { Kriteria Mutu Air Kelas II (PP } \\
\text { no.82/2001) }\end{array}$ \\
\hline
\end{tabular}

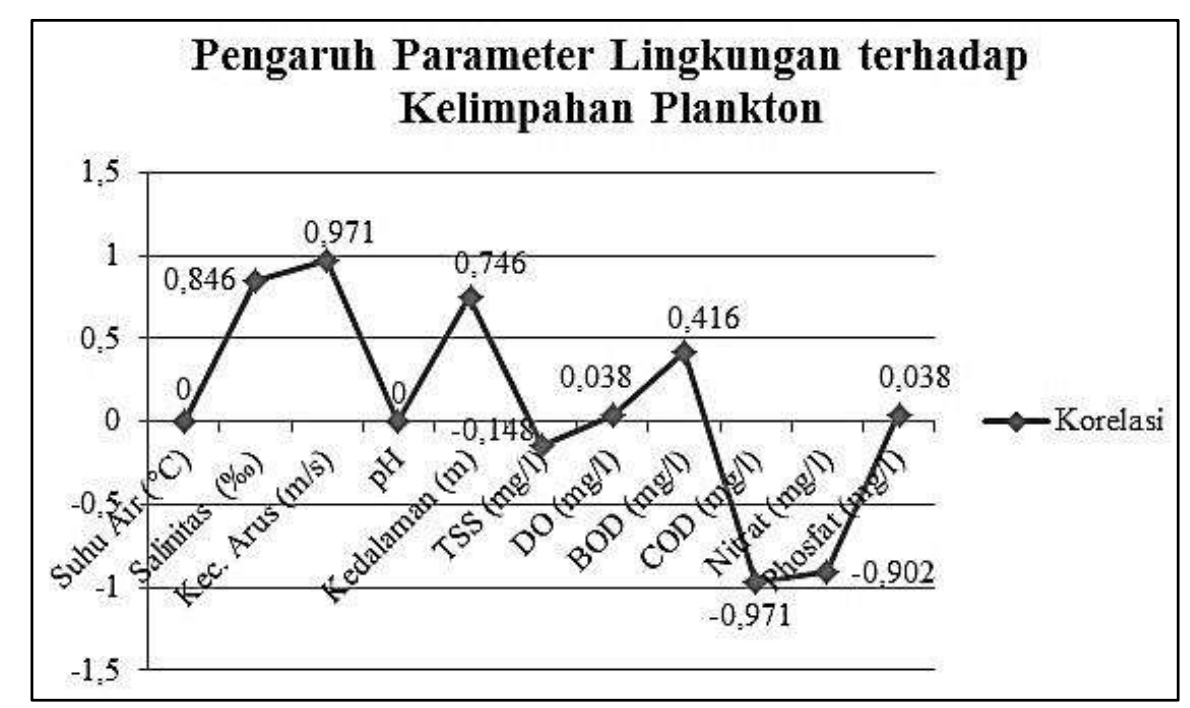

Gambar 3. Grafik Pengaruh Parameter Lingkungan terhadap Kelimpahan Organisme Plankton. 


\section{PEMBAHASAN}

\section{Komunitas Plankton}

Berdasarkan hasil penelitian dan identifikasi jenis plankton di seluruh stasiun ditemukan sebanyak 28 genera plankton yang tergolong ke dalam fitoplankton dan zooplankton. Fitoplankton terdiri dari 26 genera serta 2 genera tergolong zooplankton. Tingginya keberadaan fitoplankton dibandingkan zooplankton menunjukan bahwa ekosistem perairan di lokasi penelitian masih tergolong baik untuk membantu kelangsungan hidup fitoplankton selaku produsen utama di perairan.

Sedikitnya jenis dari zooplankton disebabkan karena jenis plankton yang termasuk ke dalam golongan fito lebih cepat meregenerasi selnya dibandingkan zooplankton yang membutuhkan waktu yang lebih lama. Sifat khas fitoplankton ini juga diperkuat dengan pernyataan Anggoro et al. (2013) dimana fitoplankton mampu berkembang secara berlipat ganda dalam waktu yang relatif singkat, tumbuh dengan kerapatan tinggi, melimpah dan terhampar luas. Adanya migrasi secara vertikal di perairan juga menentukan jumlah dari komposisi spesies plankton mengingat pengambilan data dilakukan pada saat pagi hari, selain itu juga menurut Yunita (2015) kepadatan jenis fitoplankton di perairan yang mengalir lebih tinggi dibandingkan dengan zooplankton, oleh karena itu umumnya zooplankton lebih banyak ditemukan di perairan dengan arus rendah. Hal ini terbukti dari jumlah zooplankton yang ditemukan di Muara Sungai Kurau hanya terdiri dari 2 genera yakni Nauplius sp. dan Oncaea sp.

Spesies yang paling banyak ditemukan adalah genera dari kelas Bacillariophyceae (diatom) sebanyak 23 genera diantaranya Rhizosolenia sp., Bacteriastrum sp., Chaetoceros sp., Biddulphia sp., Thalassionthrix sp., Nitzschia sp., dll. Menurut Nyabakken (1992), jenis dari kelas Bacillariophyceae ini mampu tumbuh dengan cepat meski dalam kondisi perairan yang minim nutrient dan cahaya. Plankton dari kelas ini juga memiliki kemampuan untuk beradaptasi yang tinggi serta mampu meregenarasi dan bereproduksi dengan baik sehingga jumlahnya lebih mendominasi dibandingkan genus dari kelas yang lainnya.

Beberapa penelitian terdahulu mengenai fitoplankton di muara sungai juga memperlihatkan kecendrungan dominansi dari kelas Bacillariophyceae (diatom), seperti pada penelitian Hutabarat et al., (2013) di Muara Sungai Babon Semarang ditemukan 11 genera fitoplankton dari kelas Bacillariophyceae, 4 genera dari kelas Cyanophyeae, 2 genera dari kelas Chlorophyceae dan 2 genera dari kelas Pyprophyta.

Kelimpahan plankton yang ditemukan selama penelitian bervariasi antar stasiun dalam selang waktu pengamatan yang berbeda, yakni berkisar antara 2.935 - 57.642 ind/l. Rata-rata kelimpahan plankton bila dijumlahkan pada setiap stasiun didapatkan nilai bahwa rata-rata kelimpahan tertinggi berada di stasiun I (33.689 ind/l) dan terendah di stasiun III (21.741 ind/l).
Tingginya nilai rata-rata kelimpahan plakton di stasiun I disebabkan oleh lokasi penelitian yang berada dekat dengan mulut Muara Sungai Kurau yang langsung terhubung ke laut. Muara sungai menurut Soeyasa et al., (2001) dalam Zahidin (2008) cenderung lebih produktif bila dibandingkan dengan ekosistem pembentuknya yaitu perairan tawar dan laut. Adanya penambahan bahan organik secara terus menerus yang berasal dari air sungai dan air laut semakin menyokong kehidupan plankton terutama golongan fitoplankton sebagai produsen di perairan.

Stasiun III memiliki rata-rata kelimpahan terendah yaitu sebesar 21.741 ind/l. Rendahnya nilai kelimpahan dimungkinkan karena lokasi penelitian berada agak jauh dari mulut muara Sungai Kurau sehingga minimnya pasokan air laut ke daerah ini. Semakin menjauhi daerah muara atau perairan laut kelimpahan plankton cenderung menurun terutama golongan dari zooplankton. Menurut Taurita et al., (2012) perairan yang masih dekat dengan laut cenderung memiliki jumlah spesies yang lebih bervariasi dan melimpah dibandingkan dengan plankton air tawar.

Dilihat dari nilai keanekaragaman plankton (H') di Muara Sungai Kurau pada masing-masing stasiun tergolong sedang yakni stasiun I $(2,06)$, stasiun II $(2,07)$ dan stasiun III $(2,3)$. Menurut kriteria nilai indeks keanekaragaman plankton Shannon-Wiener (Fachrul. 2007) apabila $1<H^{\prime}<3$ maka stabilitas komunitas biota sedang atau kualitas air tercemar sedang. Adanya perbedaan nilai keanekaragaman menurut Yazwar (2008), disebabkan oleh faktor fisika, kimia dan ketersediaan nutrien serta pemanfaatan nutrien tersebut oleh tiap individu.

Faktor lingkungan seperti ketersediaan bahan organik (nitrat dan Phosfat) serta kemampuan dari masing-masing individu untuk beradaptasi di lingkungan yang ada menjadi salah satu yang mempergaruhi nilai keanekaragaman plankton di perairan. Kondisi sungai yang keruh dapat menurunkan intensitas cahaya yang masuk ke dalam perairan sehingga organisme jenis fitoplankton sulit melakukan fotosintesis.

Nilai keseragaman plankton tertinggi pada stasiun III sebesar 1, serta keseragaman terendah di stasiun I $(0,28)$ dan stasiun II $(0,3)$. Tingginya nilai keseragaman di stasiun III mengindikasikan bahwa keseragaman antar spesies relatif seragam artinya tidak ada individu atau spesies yang mendominasi perairan tersebut, sedangkan pada stasiun I dan II keseragaman antar spesies rendah yang menunjukkan adanya spesies yang mendominasi perairan dalam hal ini di dominasi oleh Rhizosolenia sp. dan Chaetoceros sp. (Tabel 3). Berdasarkan kriteria indeks keseragaman Pielou, 1996 (Fachrul, 2007) apabila $\mathrm{E}=0$, maka keseragaman antar spesies rendah atau relatif tidak seragam dan apabila $\mathrm{E}$ = 1, maka keseragaman antar spesies relatif seragam. Semakin rendahnya nilai keanekaragaman maka semakin rendah pula nilai keseragaman serta semakin tinggi nilai dominansi. 


\section{Saprobik Indeks dan Tingkat Saprobik Indeks}

Nilai saprobitas perairan mencerminkan tingkat pencemaran perairan yang ditandai dengan keberadaan organisme mikroskopis seperti plankton (Hartoko, 2013). Keberadaan organisme saprobik sebagai indikator kualitas perairan diukur dari kualitas air itu sendiri seperti kandungan bahan nutrient dan bahan pencemar.

Tingginya kandungan nutrient ke arah muara dapat meningkatkan produktivitas fitoplankton. Meningkatnya produktivitas plankton di daerah muara akan mendukung meningkatnya produktivitas organisme lain yang memiliki tingkatan tropik yang lebih tinggi (Chanton dan Lewis, 2002 dalam Suryanti, 2008). Namun, apabila kandungan nutrient di perairan dalam jumlah yang berlebih akan menyebabkan blooming fitoplankton.

Selain kandungan nutrient dan bahan pencemar menurut Suryanti (2008), perbedaan jumlah organisme plankton dalam suatu perairan juga akan mempengaruhi tingkat saprobitas di perairan tersebut.

Adapun organisme saprobik yang ditemukan selama penelitian yakni Biddulphia sp., Chaetoceros sp., Nitzschia sp., Oscillatoria sp., Rhizosolenia sp., Stephanodiscus sp., termasuk kedalam kelompok $\alpha-$ Mesosaprobik dan dapat digunakan sebagai indikator bahwa perairan dalam kondisi tercemar berat. Asterionella sp., Ceratium sp., Melosira, Nauplius, termasuk ke dalam kelompok $\beta$ - Mesosaprobik yang dapat digunakan sebagai indikator perairan yang tercemar sedang serta organisme seperti Skeletonema sp., Synedra, Pinnularia sp., termasuk dalam kelompok Oligosaprobik yang dapat dijadikan sebagai indikator perairan yang tercemar ringan (Tabel 3).

Berdasarkan hasil perhitungan nilai koefisien indeks saprobik terlihat bahwa nilai koefisien indeks saprobik pada masing-masing stasiun berkisar antara $1,2-1,56$. Berdasarkan kategori pencemaran perairan menunjukkan bahwa Muara Sungai Kurau berada dalam kondisi tercemar ringan sampai dengan sedang.

Stasiun I dan II yang lokasinya sama-sama berada dekat dengan mulut muara sungai diperoleh nilai koefisien indeks saprobik (SI) yang tidak jauh berbeda yakni sebesar 1,37 dan 1,24 dan TSI sebesar 1,5 dan 1,49 yang menunjukkan keadaan kualitas airnya mengalami pencemaran ringan hingga sedang atau termasuk ke dalam kelompok $\beta$ - mesosaprobik. Berdasarkan kriteria indeks saprobitas apabila nilai SI dan TSI $0,5 \mathrm{~s} / \mathrm{d}$ 1,5 tergolong dalam kelompok $\beta-$ mesosaprobik yang berarti bahwa kondisi perairan tersebut tercemar ringan sampai sedang.

Basmi (2000) mendeskripsikan fase tersebut sebagai keadaan dimana kandungan osigen terlarut (DO) dalam perairan tinggi, bakteri sangat menurun, jumlah produsen, konsumen dan dekomposer seimbang, struktur komunitas sangat melimpah dalam hal jenis dan jumlah spesies serta menghasilkan produk akhir nitrat.

Kondisi ini disebabkan karena adanya aktivitas domestik yang terjadi seperti pemukiman, pasar dan pelabuhan bongkar muat hasil perikanan. Aktivitas tersebut menghasilkan limbah buangan baik organik maupun anorganik, seperti sisa-sisa makanan, air buangan (mandi, cuci, kakus) serta tumpahan minyak dari kapal-kapal nelayan yang langsung masuk ke perairan sungai. Menurut Zivic dan Markovic (2003) dalam Zahidin (2008) pengaruh terkuat terhadap kondisi tingkat saprobitas perairan adalah kedekatan dengan pemukiman penduduk serta adanya sedimentasi.

Berbeda dengan stasiun III yang lokasinya agak jauh dari mulut muara sungai tetapi masih terdapat aktivitas berupa tempat bersandarya kapal-kapal nelayan yang memiliki nilai SI dan TSI sebesar 1,56 dan 2,52. Hal ini mengindikasikan bahwa kondisi perairan di stasiun III masih tergolong baik. Besarnya nilai koefisien saprobik di stasiun III dapat disebabkan oleh kondisi lingkungan perairan yang jauh dari sumber pencemar. Letak stasiun III yang jauh dari aktivitas domestik menjadi salah satu faktor penyebab tingginya nilai SI dan TSI.

Berdasarkan kriteria saprobik apabila nilai SI dan TSI 1,5 s/d 2,0 maka tergolong ke dalam kelompok oligosaprobik yaitu pencemaran ringan atau belum tercemar. Fase ini terjadi disebabkan karena kondisi perairan yang belum tercemar atau mempunyai tingkat pencemaran ringan, penguraian terhadap bahan organik sempurna, kandungan oksigen terlarut (DO) di dalam periran tinggi, serta struktur komunitas dalam hal jenis dan jumlah sangat melimpah (Basmi, 2000).

\section{Pengaruh Parameter Lingkungan Terhadap Kelimpahan Organisme}

Berdasarkan kategori koefisien korelasi Siregar S (2014), parameter salinitas, kecepatan arus, COD dan nitrat memiliki korelasi yang sangat kuat $(0,80-1,00)$, parameter BOD memiliki korelasi yang cukup $(0,40-$ 0,599), parameter kedalaman memiliki korelasi kuat $(0,60-0,799)$, sedangkan parameter TSS, DO, suhu, $\mathrm{pH}$ dan phosfat memiliki korelasi sangat lemah $(0,00-$ $0,199)$.

Secara fisik Muara Sungai Kurau memiliki suhu rata-rata $26,7^{\circ} \mathrm{C}$ dengan $\mathrm{pH}$ sebesar 6 yang menunjukan bahwa kondisi ini masih mendukung untuk kelangsungan hidup organisme perairan terutama plankton. Plankton akan tumbuh dan berkembang biak dengan baik pada kisaran suhu tersebut. Suhu berperan sangat penting terutama bagi organisme fitoplankton untuk membantu proses-proses fisiologis, yaitu proses fotosintesis, respirasi, metabolisme dan reproduksi. Proses-proses fisiologis tersebut akan menurun tajam apabila suhu perairan berada diluar kisaran optimal.

Menurut Hartoko (2013), suhu air yang optimum bagi pertumbuhan plankton di perairan tropis berkisar antara $25^{\circ} \mathrm{C}-32^{\circ} \mathrm{C}$. Sedangkan menurut Effendi (2003), algae dari filum Chlorophyta dan diatom akan tumbuh dengan baik pada kisaran suhu berturut-turur $30^{\circ} \mathrm{C}-35^{\circ} \mathrm{C}$ dan $20^{\circ} \mathrm{C}-30^{\circ} \mathrm{C}$ sedangkan, menurut Effendi (2003) pH normal adalah 6 - 8 dan air 
sungai dalam kondisi alami yang belum tercemar memiliki rentang $\mathrm{pH}$ sebesar 6,5-8,5.

Parameter lingkungan seperti salinitas $(0,846)$, kecepatan arus $(0,971)$, kedalaman $(0,746)$, DO $(0,038)$, BOD $(0,416)$ dan phosfat $(0,038)$ memiliki hubungan yang searah (bernilai positif) terhadap kelimpahan organisme plankton, artinya semakin besar nilai parameter fisika kimia perairan maka nilai kelimpahan akan semakin besar pula. Parameter lingkungan lain seperti TSS (-0,148), COD (-0,971) dan nitrat $(-0,902)$ memiliki hubungan yang bebanding terbalik (bernilai negatif) terhadap kelimpahan plankton, artinya semakin besar nilai parameter fisika kimia perairan maka nilai kelimpahan akan semakin kecil.

Distribusi dan kelimpahan plankton yang diperoleh selama tiga kali pengambilan data cenderung tidak jauh berbeda. Arus merupakan faktor utama yang membatasi penyebaran organisme dalam suatu perairan mengingat plankton merupakan organisme yang hidupnya dipengaruhi oleh arus. Perubahan arus yang terjadi secara terus menerus tentu akan menyebabkan perubahan pada kelimpahan, keanekaragaman, keseragaman dan dominansi plankton.

Kecepatan arus di Perairan Muara Sungai Kurau berkisar antara $0,323-0,363 \mathrm{~m} / \mathrm{s}$. Menurut Suryanti (2008), kecepatan arus akan meningkat ketika kondisi air pasang, sehingga plankton yang ada di laut akan terbawa arus masuk ke daerah muara sungai sehingga kelimpahan plankton pada kondisi ini akan meningkat.

Salinitas di Muara Sungai Kurau berkisar antara $18 \%$ - 18,7\%o, hal ini disebabkan karena lokasi penelitian yang dekat dengan mulut muara sungai. Hasil penelitian ini sejalan dengan pernyataan Nyabaken (1992) bahwa salinitas di suatu perairan muara memiliki tingkat salinitas antara 5\% - 30\%o. Menurut Hartoko (2013) pada kondisi salinitas tinggi plankton akan dapat tumbuh dengan baik sementara itu, pada kondisi salinitas rendah organisme plankton cenderung sulit untuk bertahan sehingga salinitas akan berpengaruh terhadap kelimpahan dan keberadaan plankton.

Kelimpahan fitoplankton ini juga dipengaruhi oleh ketersediaan oksigen terlarut (DO) di perairan. Apabila didasarkan pada pernyataan Boyd (1982) dalam Yunita, (2015) kandungan DO di perairan Muara Sungai Kurau masih dapat ditolerir oleh organisme akuatik terutama fitoplankton dalam hal ini kadar DO tidak kurang dari $5 \mathrm{mg} / \mathrm{l}$.

Suryanto et al., (2014) menyatakan bahwa penyebab utama kekurangan oksigen terlarut dalam air adalah adanya bahan-bahan buangan yang biasanya mudah diuraikan oleh bakteri dengan bantuan oksigen. Oksigen dalam air di konsumsi oleh bakteri untuk menguraikan bahan tersebut. Bahan-bahan tersebut dapat berasal dari kotoran hewan maupun manusia, tanaman mati atau sampah organik, bahan-bahan dari industri pangan, pemotongan hewan dan ikan.

Phosfat yang dibutuhkan fitoplankton dalam pertumbuhannya sebesar $0,09-1,80 \mathrm{mg} / \mathrm{l}$. Kisaran ini jika dibandingkan dengan hasil pengamatan maka didapatkan hasil bahwa perairan Muara Sungai Kurau merupakan perairan yang memiliki kategori kesuburan rendah (oligotrofik) yakni dari hasil pengukuran nilai phosfat (PO4) sebesar 0,0067 - 0,007 mg/l.

Perairan Muara Sungai Kurau memiliki nilai TSS yang relatif tinggi yakni berkisar antara 133 - 158 mg/l. Tingginya nilai TSS di muara sungai disebabkan banyaknya bahan organik yang terbawa oleh arus hingga ke muara. Selain itu kondisi muara yang merupakan jalur keluar masuknya kapal-kapal nelayan juga menjadi salah satu faktor penyebab tingginya nilai TSS di area tersebut. Efek lain yang ditimbulkan dari tingginya nilai TSS di perairan yakni rendahnya penetrasi cahaya yang masuk ke perairan. rendahnya cahaya ini dapat mengganggu proses fotosintesis dan mengurangi produktivitas primer oleh organisme fitoplankton di perairan (Zweig et al,. 1999 dalam Hartoko. 2013).

Ditinjau dari nilai rata-rata COD yang berkisar antara 28 - $38 \mathrm{mg} / \mathrm{l}$ menunjukan bahwa limbah yang masuk ke perairan masih dapat didegradasi oleh organisme pengurai. Basmi (2000) menyatakan bahwa, hasil oksidasi ataupun dekomposisi mikroba berupa bahan organik dapat dimanfaatkan perifiton dan fitoplankton untuk pertumbuhannya atau sebagai makanannya.

Dari hasil analisa nitrat pada masing-masing stasiun amatan (Tabel 5.), didapatkan hasil yakni nitrat (NO3) sebesar 0,017 - 0,025 mg/l menunjukan bahwa tingkat kesuburan perairannya adalah oligotrofik. Fitoplankton dalam pertumbuhannya memerlukan kandungan nitrat pada kisaran 0,9 - 3,5 mg/l. Kisaran ini jika dibandingkan dengan hasil pengamatan maka didapatkan hasil bahwa perairan Muara Sungai Kurau merupakan perairan yang memiliki kategori kesuburan rendah (oligotrofik).

Menurut Mustofa (2013), perairan muara sungai memiliki kandungan nitrat (NO3) lebih sedikit dibandingkan dengan perairan dekat mangrove. Hal ini disebabkan karena kandungan lumpur yang merupakan material tanah yang masuk kelaut bersamaan dengan air tawar dan mengendap tertahan oleh energi laut. Material endapan ini sedikit mengandung organisme yang mampu mengurai mineral dan mendekomposisi bahan-bahan organik menjadi nitrat dan phosfat. Akibatnya kandungan nitrat dan phosfat menjadi sedikit dibandingkan dengan perairan dekat dengan mangrove.

\section{SIMPULAN DAN SARAN Simpulan}

Berdasarkan hasil penelitian, maka dapat disimpulkan sebagai berikut :

1. Nilai keofisien saprobik plankton pada stasiun I dan II di Muara Sungai Kurau berturut-turut berkisar antara 1,37 dan 1,24 (SI) serta 1,5 dan 1,49 (TSI) yaitu perairan yang tercemar ringan hingga sedang. Sedangkan stasiun III tergolong 
perairan yang tercemar ringan dengan nilai SI $(1,56)$ dan TSI $(2,52)$.

2. Berdasarkan analisis koefisien korelasi, parameter salinitas, kecepatan arus, COD, nitrat dan kedalaman memiliki korelasi yang sangat kuat $(>0,75-0,99)$. Oksigen terlarut (DO), BOD dan phosfat memiliki korelasi yang cukup $(>0,25$ $0,50)$ sedangkan, parameter suhu dan $\mathrm{pH}$ tidak memiliki korelasi terhadap kelimpahan plankton (0).

\section{Saran}

Pembuangan limbah yang terjadi di Muara Sungai Kurau harus lebih dikurangi untuk mencegah terjadinya pencemaran yang lebih lanjut. Selain itu, perlu juga dilakukan penelitian mengenai saprobitas perairan dengan bioindikator makrozoobentos.

\section{DAFTAR PUSTAKA}

Anggoro, S., P. Soedarsono, dan Suprobo. H.D. 2013. Penilaian Pencemaran Perairan di Polder Tawang Semarang ditinjua dari Aspek Saprobitas. Journal of Management of Aquatic Resources 2 (3), 109118.

Badan Lingkungan Hidup Daerah (BLHD) Provinsi Bangka Belitung. 2015. Laporan Kegiatan Pemantauan Kualitas Air Sungai dan Penentuan Status Mutu Sungai Provinsi Kepulauan Bangka Belitung.

Basmi J. 2000. PLANKTONOLOGI : Plankton Sebgai Bioindikator Kualitas Perairan. Fakultas Perikanan dan Ilmu Kelautan, Institut Pertanian Bogor.

Effendi H. 2003. Telaah kualitas air bagi pengelolaan sumberdaya dan lingkungan perairan. Kanisius : Yogyakarta

Fachrul M F. 2007. Metode Sampling Bioekologi. Bumi Aksara : Jakarta

Hartoko A. 2013. Oceanographic Characters and Plankton Resources of Indonesia. Graha Ilmu. Yogyakarta.

Hutabarat S., Soedarsono P., Cahyaingtyas I. 2013. Studi Analisa Plankton untuk Menentukan Tingkat Pencemaran di Muara Sungai Babon Semarang. Jurnal of Management of Aquatic Resources. 2 (3) : 74-84

Iranawati F., Sari S H J., Choirun A. 2015. Identifikasi Fitoplankton Spesies Harmfull Algae Bloom (HAB) saat Kondisi Pasang di Perairan Pesisir Brondong, Lamongan, Jawa Timur. Jurnal Ilmu Kelautan dan Perikanan. 25 (2) : 58-66
Mustofa A. 2015. Kandungan Nitrat dan Pospat sebagai Faktor Tingkat Kesuburan Perairan Pantai. Jurnal Disprotek. 6 (1) : 13-19

Nyabakken, J.W. 1992. Biologi Laut Suatu Pendekatan Ekologis. Alih bahasa: M. Eidman., Koesoebiono, D.G. Bengen dan M. Hutomo. Gramedia. Jakarta.

Peraturan Menteri Kesehatan Republik Indonesia No. 416 Tahun 1990 Tentang Standar Kualitas Air Bersih dan Air Minum

Peraturan Pemerintah Republik Indonesia No. 82 Tahun 2001 Tentang Pengelolaan Kualitas Air dan Pengendalian Pencemaran Air.

Salmin. 2005. Oksigen Terlarut (DO) dan Kebutuhan Oksigen Biologi (BOD) sebagai Salah Satu Indikator untuk Menentukan Kualitas Perairan. Oseana. 30 (3) : 21-26

Siregar Syofian. 2014. Statistik Parametrik untuk Penelitian Kuantitatif Dilengkapi dengan Perhitungan Manual dan Aplikasi SPSS Versi 17. Bumi Aksara. Jakarta

Suryanti. 2008. Kajian Tingkat Saprobitas Di Muara Sungai Morodemak Pada Saat Pasang dan Surut. Jurnal Saintek Perikanan. 4 (1) : 76-83

Suryanto A. Suryanti. Ersa M M S. 2014. Analisa Status Pencemaran dengan Indeks Saprobitas Di Sugai Klampisan Kawasan Industri Candi Semarang. Deponegoro Journal Of Maquares. 3 (4) : 216-224

Taurita H., Dharmawan A., Yani N G., 2012. Komposisi Zooplankton (Outlet) pada Area Perairan di Tambak Sungai Kalisodok Kabupaten Pasuruan Jawa Timur. Jurusan Biologi Universitas Negeri Malang. Jurnal (tidak dipublikasikan).

Yazwar. 2008. Keanekaragaman Plankton dan Keterkaitannya dengan Kualitas Air di Parapat Danau Toba. [Tesis]. Program Studi Bioloi, Universitas Sumatera Utara, Medan.

Yunita E., Priyanti., Maresi S R P. 2015. Plankton sebagai Bioindikator Saprobitas Perairan di Situ Bulakan Kota Tanggerang. Jurnal Biologi. 8 (2) : 113-122

Zahidin M. 2008. Kajian Kualitas Air di Muara Sungai Pekalongan Ditinjau dari Indeks Keanekaragaman Makrobenthos dan Indeks Saprobitas Plankton. [Tesis]. Program Studi Manajemen Sumberdaya Perairan, Universitas Diponegoro. 